\title{
Efforts to Improve Learning Outcomes of Class V Students Using Interactive Powerpoint Media
}

\author{
Ilham Ardiansyah
}

SD Negeri Cawitali 03

iyanardiansyah24@gmail.com

\section{Article History}

accepted 01/11/2020

approved 08/11/2020

published 15/11/2020

\begin{abstract}
The background of this study is the low learning outcomes of students as evidenced by the low score of evaluation test results. The goal to be achieved is the use of interactive powerpoint media to improve student learning outcomes. The effort made by the writer is improving learning by using interactive powerpoint learning media. This research method uses classroom action research which takes place in three cycles, each cycle consisting of 1) planning; 2) action, 3) observation and 4) reflection. The subjects of this study were 24 students of grade V SD Negeri Cawitali 03. Efforts to improve learning have been successful and end in the third cycle. This can be seen in Cycle I, students who complete learning are 16 students from 24 students = $67 \%$, Cycle II students who complete learning are 19 students out of 24 students $=79.2 \%$ and Cycle III students who complete learning are 23 students out of 24. Students $=95.8 \%$. Based on the results obtained, it can be concluded that the learning outcomes of the circulatory system material in grade V SD Negeri Cawitali 03 can be increased by using interactive powerpoint media.
\end{abstract}

Keywords: Learning Outcomes, Interactive Powerpoint Media

\begin{abstract}
Abstrak
Latar belakang penelitian ini adalah rendahnya hasil belajar peserta didik yang dibuktikan dengan nilai hasil tes evaluasi yang masih rendah.Tujuan yang hendak dicapai adalah penggunaan media powerpoint interaktif dapat meningkatkan hasil belajar peserta didik. Upaya yang dilakukan penulis adalah perbaikan pembelajaran dengan menggunakan media pembelajaran powerpoint interaktif. Metode penelitian ini menggunakan penelitian tindakan kelas yang berlangsung dalam tiga siklus, setiap siklus terdiri atas 1) perencanaan;2) tindakan, 3) pengamatan dan 4) refleksi. Subjek penelitian ini adalah peserta didik kelas V SD Negeri Cawitali 03 sebanyak 24 peserta didik. Upaya perbaikan pembelajaran telah berhasil dan berakhir pada siklus ketiga. Hal ini terlihat pada Siklus I, siswa yang tuntas belajar sebanyak 16 Siswa dari 24 Siswa $=67 \%$, Siklus II siswa yang tuntas belajar sebanyak 19 Siswa dari 24 Siswa $=79,2 \%$ dan Siklus III siswa yang tuntas belajar sebanyak 23 Siswa dari 24 Siswa = $95,8 \%$. Berdasarkan hasil penelitian yang diperoleh dapat disimpulkan bahwa hasil belajar materi sistem peredaran darah pada peserta didik kelas V SD Negeri Cawitali 03 dapat meningkat dengan menggunakan media powerpoint interaktif.
\end{abstract}

Kata kunci: Hasil Belajar, Media Powerpoint interaktif

Social, Humanities, and Education Studies (SHEs): Conference Series https://jurnal.uns.ac.id/shes

p-ISSN 2620-9284

e-ISSN 2620-9292 


\section{PENDAHULUAN}

Pada proses belajar mengajar sering dijumpai adanya peserta didik yang hasil belajarnya masih rendah dan kurang aktif dalam mengikuti proses pembelajaran. Hal ini ditunjukan dengan hasil belajar yang masih kurang maksimal dan juga kurangnya minat peserta didik untuk mengajukan pertanyaan kepada guru sehubungan dengan materi pelajaran yang sedang berlangsung. Agar minat dan hasil belajar peserta didik dapat tumbuh dan berkembang secara baik, guru perlu meningkatkan hasil belajar peserta didik dalam pembelajaran, karena peranan guru sangat berpengaruh dalam penciptaan suasana pembelajaran yang dapat meningkatkan aktivitas dan disiplin belajar peserta didik. Oleh karena itu guru dituntut untuk kreatif dalam menggunakan model-model pembelajaran yang dapat membuat peserta didik senang, nyaman dan tidak cepat bosan sehingga tercipta suasana belajar yang ideal dan tujuan belajar dapat tercapai secara maksimal. Menurut Kayatun (2014) hasil belajar merupakan hasil yang diperoleh peserta didik setelah terjadinya proses pembelajaran yang ditunjukkan dengan nilai tes yang diberikan oleh guru setiap selesai memberikan materi pembelajaran pada satu pokok bahasan. Faktor-faktor yang memengaruhi hasil belajar antara lain meliputi faktor internal : (1) Faktor Fisiologis, (2) Faktor Psikologis, sedangkan faktor eksternal : (1) Faktor lingkungan, (2) Faktor Instrumental. Di dalam dunia pendidikan, terdapat banyak cabang ilmu pengetahuan salah satunya yaitu IImu Pengetahuan Alam (IPA). IImu Pengetahuan Alam atau biasa disebut IPA merupakan dasar ilmu yang melahirkan teknologi modern yang mempelajari tentang gejala alam dan kebendaan yang terjadi di sekitar kita yang tersusun secara teratur serta cara pemecahan masalahnya berdasarkan hasil observasi maupun eksperimen. IImu Pengetahuan Alam (IPA) juga termasuk salah satu mata pelajaran yang sudah dipelajari pada jenjang Sekolah Dasar.

Pendidikan IPA di sekolah dasar sendiri pada hakikatnya bertujuan agar peserta didik menguasai pengetahuan dan fakta tentang alam sekitar berdasarkan kehidupan sehari- hari. Pendidikan IPA juga menekankan pada pengalaman peserta didik secara langsung untuk mencari tahu permasalahan yang ada di sekitar serta cara pemecahan masalahnya, sehingga peserta didik mampu menjelajahi dan memahami alam sekitar secara ilmiah. Mata pelajaran ini juga termasuk salah satu mata pelajaran yang dianggap sulit bagi sebagian peserta didik pada tingkat Sekolah Dasar. Berdasarkan fakta di lapangan masih banyak peserta didik kelas V di SD Negeri Cawitali 03 yang hasil belajarnya masih rendah, bahkan ada peserta didik yang tidak bisa mengerjakan soal atau jika mengerjakan soal pun jawaban tidak sesuai dengan seharusnya. Peserta didik tidak terlihat aktif pada saat pembelajaran berlangsung karena kurang memahami penjelasan guru. Selain itu, penggunaan media pembelajaran yang kurang menarik bagi peserta didik. Serta kurangnya minat belajar peserta didik dalam mengikuti kegiatan pembelajaran menjadikan pembelajaran yang kurang maksimal. $\mathrm{Hal}$ ini dibuktikan dari hasil ulangan harian maupun ulangan semester yang diperoleh peserta didik sebagian besar nilainya di bawah KKM (Kriteria Ketuntasan Minimal).

Berdasarkan latar belakang masalah diatas maka peneliti akan mengembangkan media pembelajaran berbasis TIK yaitu Powerpoint Interaktif sebagai alat bantu guru dalam mengajarkan materi sistem peredaran darah. Penggunaan media Powerpoint Interaktif memberikan gambaran konkrit mengenai pembelajaran IPA yang bersifat abstrak. Media Powerpoint Interaktif dapat menampilkan berbagai menu yang berisi materi, kuis, video gambar yang bersifat interaktif. Interaktif merupakan hubungan timbal balik dari pengirim pesan ke penerima pesan. Sehingga media Powerpoint Interaktif ini diharapkan dapat lebih menarik perhatian peserta didik dan mengatasi kebosanan serta dapat meningkatkan hasil belajar peserta didik dalam proses pembelajaran. Oleh karena itu, penulis melakukan penelitian tindakan kelas yang berjudul "Upaya Peningkatan Hasil Belajar Peserta didik Kelas V Pada Materi Sistem Peredaran Darah dengan Menggunakan Media 
Powerpoint Interaktif Di SD Negeri Cawitali 03 Kecamatan Bumijawa Kabupaten Tegal".

\section{METODE}

Penelitian ini merupakan Penelitian Tindakan Kelas ( PTK) yang berlangsung dalam tiga siklus, setiap siklus terdiri atas 1) perencanaan (planning), 2) pelaksanaan tindakan (action), 3) pengamatan (observation) dan 4) refleksi (reflection). Subjek penelitian ini adalah peserta didik kelas V SD Negeri Cawitali 03 sebanyak 24 peserta didik. Data yang dianalisis berupa data kualitatif yaitu penggunaan media powerpoint interaktif untuk meningkatkan hasil belajar peserta didik. Teknik pengumpulan data dalam penelitian tindakan kelas ini adalah berupa observasi, tes, dan dokumentasi. Analisis data hasil penelitian tindakan kelas dengan statistic deskriptif (statistik sederhana) yaitu analisis data sederhana. Untuk menganalisis dan menginterpretasi data dapat menggunakan tabel konversi yaitu data kualitatif dapat dikonversi menjadi kuantitatif atau sebaliknya

\section{A. Hasil Penelitian}

\section{HASIL DAN PEMBAHASAN}

\section{Deskripsi Hasil Data Penelitian Siklus I}

Pelaksanaan Penelitian siklus I dilaksanakan satu kali pertemuan (satu tindakan), dilaksanakan di kelas V SD Negeri Cawitali 03 secara daring dengan observer Ade Miftakhul Ulum, S.Pd, pada hari Kamis tanggal 22 Oktober 2020. Materi yang disampaikan yaitu Tema 4 Subtema 1 Pembelajaran 1. Adapun data yang diperoleh dari pelaksanaan Siklus I terdiri dari penilaian belajar aspek sikap, aspek keterampilan dan aspek pengetahuan. Data penelitian diperoleh dari siklus yang terdiri dari empat tahapan yaitu perencanaan, tindakan, pengamatan, dan refleksi. Adapun hasil penelitian dapat peneliti uraikan sebagai berikut:

a. Perencanaan

Pada tahap ini peneliti melakukan analisis materi pembelajaran yang diajarkan yaitu pada Tema 4 Subtema 1 Pembelajaran ke 1 yang meliputi mata pelajaran IPA dan Bahasa Indonesia. Setelah memahami materi pembelajaran yang akan diajarkan, peneliti mempersiapkan Rencana Pelakanaan Pembelajaran (RPP), Soal Evaluasi, dan segala sesuatu yang diperlukan untuk pembelajaran.

b. Tindakan

Pada tahap pelaksanaan siklus 1 peneliti melakukan pertemuan sebanyak satu kali dan dilaksanakan selama 4 × 35 menit atau 4JP.

c. Observasi

Kegiatan observasi pada siklus pertama dilakukan untuk mengamati pembelajaran guru dan peserta didik dikelas juga dilakukan pengamatan untuk mengisi rubrik penilaian afektif dan penilaian psikomotorik yang bertujuan untuk mendukung data yang diperoleh peneliti. Tetapi pada penelitian ini tidak dibahas secara rinci mengenai hasil belajar afektif dan psikomotor karena hanya berfokus pada penilaian aspek pengetahuan.

Berdasarkan hasil pengamatan dan juga analisis data, dapat diketahui bahwa 16 peserta didik telah mencapai KKM dan lainnya yaitu 8 peserta didik masih dibawah KKM. Dalam siklus I indikator keberhasilan yang ditetapkan oleh peneliti adalah $60 \%$ dan pada kenyataanya peningkatan pada siklus I hanya sebesar $67 \%$ artinya bahwa hanya selisih $7 \%$ dari indikator keberhasilan yang ditetapkan oleh peneliti. Hal tersebut dikarenakan ada beberapa hal yang masih kurang maksimal pada 
penelitian siklus I, antara lain yaitu peserta didik kurang bersemangat karena hanya menggunakan buku teks (Buku Peserta didik) saat pembelajaran. Selain membuat peserta didik kurang semangat ternyata hal tersebut juga menyebabkan peserta didik bosan dan tidak konsentrasi dalam kegiatan pembelajaran. Karena hal tersebut maka pencapaian nilai pada siklus I kurang maksimal sehingga peneliti akan melanjutkan pada siklus II.

d. Refleksi

Pelaksanaan siklus I sudah sesuai dengan Rencana Pelaksanaan Pembelajaran yang dibuat oleh peneliti. Pertemuan siklus pertama dilaksanakan pada tanggal 22 Oktober 2020 Aktivitas pada pertemuan siklus pertama yaitu belajar Tema 4, Subtema 1, Pembelajaran ke 1 dengan menggunakan menggunakan metode ceramah dan penggunaan buku teks (buku peserta didik). Berdasarkan hasil pembelajaran Siklus I, hasil belajar peserta didik masih rendah. Beberapa peserta didik masih kurang memperhatikan pelajaran dan penjelasan guru dan bermain sendiri. Hasil evaluasi pembelajaran siklus 1 ini juga menunjukkan bahwa pemahaman peserta didik masih rendah. Berdasarkan hal tersebut maka perlu ada perbaikan di pembelajaran siklus II dengan mengggunakan media powerpoint interaktif agar dapat meningkatkan hasil belajar peserta didik.

\section{Deskripsi Hasil Data Penelitian Siklus II}

Untuk melaksanakan siklus II secara teknis hampir sama dengan pelaksanaan siklus I perbedaannya terletak pada kegiatan inti pembelajaran. Pada siklus II ada kegiatan diskusi sesama peserta didik dalam pemecahan masalah. Pelaksanaan Penelitian siklus II dilaksanakan satu kali pertemuan (satu tindakan), dilaksanakan di kelas $\mathrm{V}$ secara daring dengan observer Ade Miftakhul Ulum, S.Pd, pada hari Senin tanggal 2 November 2020 pukul 08.0009.45 WIB. Materi yang disampaikan yaitu Tema 4 Subtema 2 Pembelajaran 1. Adapun data yang diperoleh dari pelaksanaan Siklus II terdiri dari penilaian belajar aspek sikap, aspek keterampilan dan aspek pengetahuan. Paparan data akan di sajikan sebagai berikut:

a. Perencanaan

Pada tahap ini peneliti melakukan analisis materi pembelajaran yang diajarkan yaitu pada Tema 4 Subtema 2 Pembelajaran ke 1 yang meliputi mata pelajaran IPA dan Bahasa Indonesia. Setelah memahami materi pembelajaran yang akan diajarkan, peneliti mempersiapkan Rencana Pelakanaan Pembelajaran (RPP), Soal Evaluasi, dan segala sesuatu yang diperlukan untuk pembelajaran.

b. Tindakan

Pada tahap pelaksanaan siklus II peneliti melakukan pertemuan sebanyak satu kali dan dilaksanakan selama 4 × 35 menit atau 4JP.

c. Observasi

Kegiatan observasi pada siklus kedua dilakukan untuk mengamati pembelajaran guru dan peserta didik dikelas juga dilakukan pengamatan untuk mengisi rubrik penilaian afektif dan penilaian psikomotorik yang bertujuan untuk mendukung data yang diperoleh peneliti. Tetapi pada penenlitian ini tidak dibahas secara rinci mengenai hasil belajar afektif dan psikomotor karena hanya berfokus pada penilaian aspek pengetahuan . Dalam penilaian aspek afektif dan psikomotrorik guru menilai peserta didik dengan rubrik yang telah dibuat peneliti dan kemudian menilai berdasarkan aktivitas yang dilakukan peserta didik ketika menggambar 
dan melakukan presentasi didepan kelas. Dalam penilaian aspek afektif dan psikomotor guru dibantu dengan menggunakan catatan anekdot yang juga sebagai arsip dalam penelitian. Jadi, dalam observasi peneliti sendiri yang digunakan sebagai instrumen maka dari itu peneliti bebas melakukan pengamatan, mencatat apa yang tertarik, melakukan analisis dan kemudian dibuat kesimpulan. Pada penilaian aspek pengetahuan guru menilai peserta didik dengan menggunakan soal evaluasi yang telah dibuat oleh peneliti dan kemudian menilai hasil evaluasi yang telah dikerjakan oleh peserta didik.

d. Refleksi

Pelaksanaan siklus II sudah sesuai dengan Rencana Pelaksanaan Pembelajaran yang dibuat oleh peneliti. Pertemuan siklus kedua dilaksanakan pada tanggal 02 November 2020. Aktivitas pada pertemuan siklus kedua yaitu belajar Tema 4, Subtema 2, Pembelajaran ke 1 dengan menggunakan menggunakan metode ceramah dan penggunaan buku teks (buku peserta didik) serta menggunakan media powerpoint interaktif. Berdasarkan table 4.4 dapat diketahui bahwa 19 peserta didik telah mencapai KKM dan lainnya yaitu 5 peserta didik masih dibawah KKM. Berdasarkan hasil pembelajaran Siklus II, hasil belajar peserta didik mengalami peningkatan yang lebih baik. Pada siklus I dengan nilai ratarata 74 dan presentase ketuntasannyayaitu 67\%, pada siklus II dengan nilai rata-rata 77,8 dan presentase ketuntasannya yaitu $79,2 \%$. Oleh karena itu perlu ada perbaikan tindak lanjut, sebab peningkatan ketuntasan pada hasil belajar di siklus II belum maksimal sehingga perlu dilanjutkan ke siklus III.

\section{Deskripsi Hasil Data Penelitian Siklus III}

Pada siklus II ada kegiatan diskusi sesama peserta didik dalam pemecahan masalah. Pelaksanaan Penelitian siklus III dilaksanakan satu kali pertemuan (satu tindakan), dilaksanakan di kelas $\mathrm{V}$ secara daring dengan observer Ade Miftakhul Ulum, S.Pd, pada hari Jum'at tanggal 13 November 2020 pukul 08.00-09.45 WIB. Materi yang disampaikan yaitu Tema 4 Subtema 3 Pembelajaran 1. Adapun data yang diperoleh dari pelaksanaan Siklus III terdiri dari penilaian belajar aspek sikap, aspek keterampilan dan aspek pengetahuan. Paparan data akan di sajikan sebagai berikut:

\section{Perencanaan}

Pada tahap ini peneliti melakukan analisis materi pembelajaran yang diajarkan yaitu pada Tema 4 Subtema 3 Pembelajaran ke 1 yang meliputi mata pelajaran IPA dan Bahasa Indonesia. Setelah memahami materi pembelajaran yang akan diajarkan, peneliti mempersiapkan Rencana Pelakanaan Pembelajaran (RPP), Soal Evaluasi, dan segala sesuatu yang diperlukan untuk pembelajaran.

2. Tindakan

Pada tahap pelaksanaan siklus III peneliti melakukan pertemuan sebanyak satu kali dan dilaksanakan selama 4 × 35 menit atau 4JP.

3. Observasi

Berdasarkan hasil pengamatan dan analisis data dapat diketahui bahwa 23 peserta didik telah mencapai KKM dan lainnya yaitu 1 peserta didik masih dibawah KKM. Berdasarkan hasil pembelajaran Siklus III, hasil belajar peserta didik mengalami peningkatan yang lebih baik. Pada siklus III dengan nilai rata-rata 81,8 dan presentase ketuntasannya yaitu 95,8\%. Dengan adanya peningkatan hasil belajar yang lebih baik dibandingkan siklus 1 dan II serta ketuntasan diatas $75 \%$. Oleh karena itu tidak perlu 
ada perbaikan lanjut, sebab telah terjadi peningkatan ketuntasan pada hasil belajar di siklus III.

4. Refleksi

Pelaksanaan siklus III sudah sesuai dengan Rencana Pelaksanaan Pembelajaran yang dibuat oleh peneliti. Pertemuan siklus ketiga dilaksanakan pada tanggal 13 November 2020. Aktivitas pada pertemuan siklus ketiga yaitu belajar Tema 4 ,Subtema 3, Pembelajaran ke 1 dengan menggunakan menggunakan metode ceramah dan penggunaan buku teks (buku peserta didik) serta menggunakan media powerpoint interaktif. Berdasarkan hasil pembelajaran Siklus III, hasil belajar peserta didik mengalami peningkatan yang sangat baik. Pada siklus I dengan nilai ratarata 74 dan presentase ketuntasannyayaitu $67 \%$, pada siklus II dengan nilai rata-rata 77,8 dan presentase ketuntasannya yaitu $79,2 \%$, pada siklus III dengan nilai rata-rata 81,8 dan presentase ketuntasannya $95,8 \%$. Oleh karena itu tidak perlu ada perbaikan lanjut, sebab telah terjadi peningkatan ketuntasan pada hasil belajar di siklus III.

\section{B. Pembahasan Hasil Penelitian}

\section{Data Hasil Observasi}

Berdasarkan hasil penelitian yang telah dilakukan pada setiap siklus, maka data hasil observasi dapat penulis tunjukkan pada gambar 1. di bawah ini.

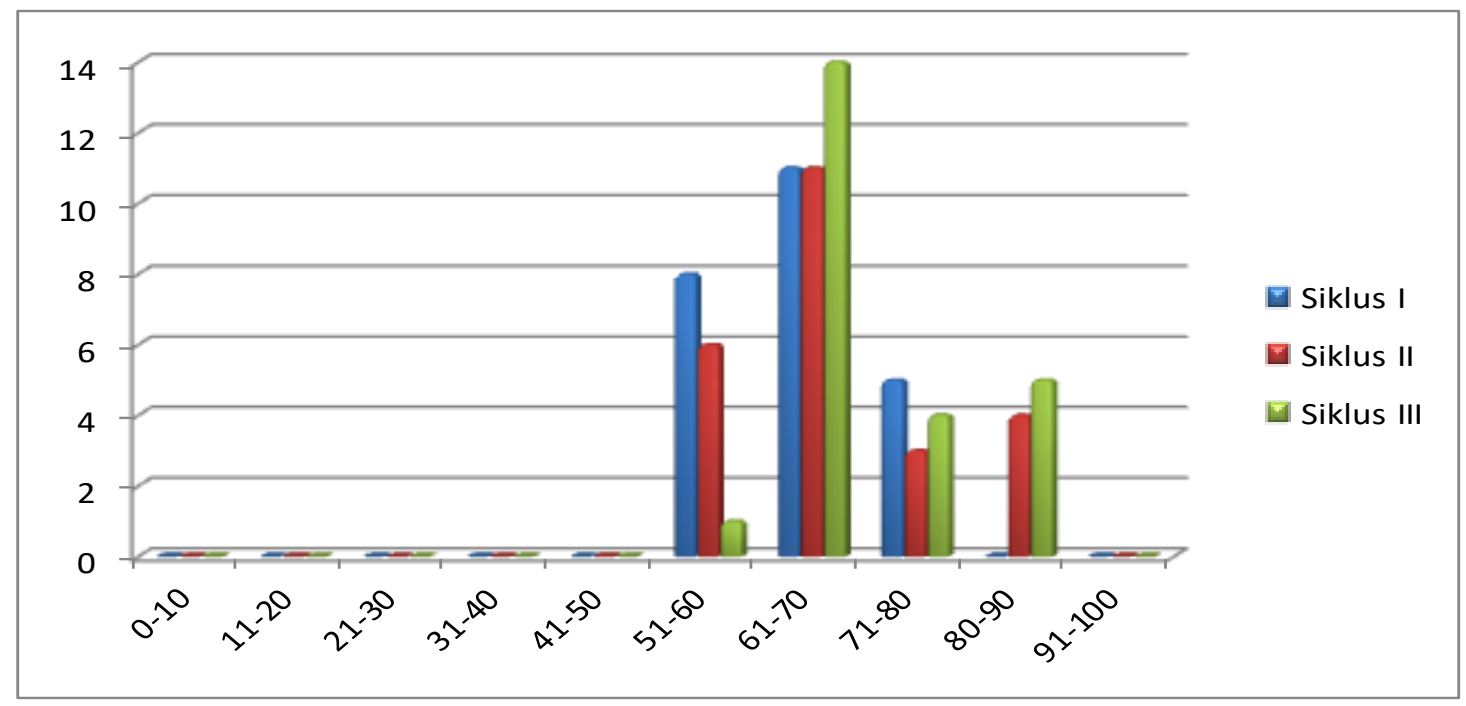

Gambar 1. Diagram Nilai Hasil Belajar Siklus I, Siklus II \& Siklus III 


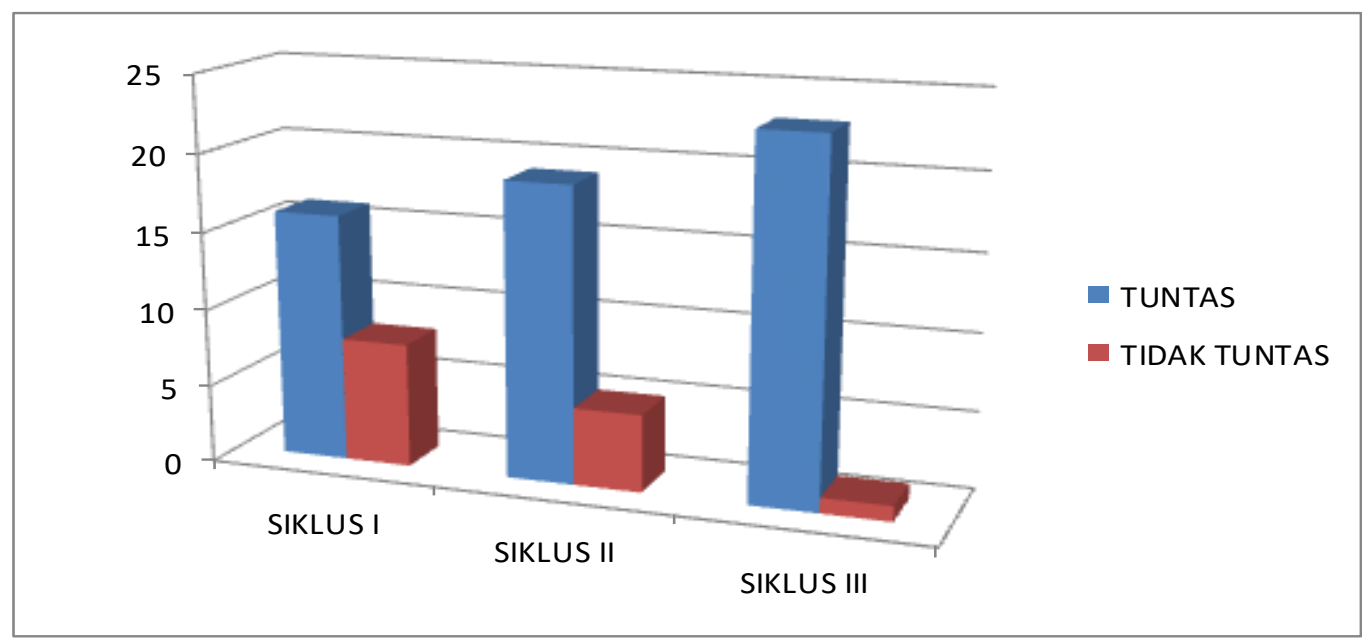

Gambar 2. Diagram Ketuntasan Belajar Siklus I, Siklus II \& Siklus III

Dari tabel 2. diperoleh keterangan sebagai berikut, Siklus I, peserta didik yang tuntas belajar sebanyak 16 peserta didik dari jumlah 24 peserta didik $=67 \%$. Siklus II, peserta didik yang tuntas belajar sebanyak 19 peserta didik dari jumlah 24 peserta didik $=79,2 \%$. Siklus III, peserta didik yang tuntas belajar sebanyak 23 peserta didik dari jumlah 24 peserta didik $=95,8 \%$

Tabel 2. Ketuntasan Siklus I, Siklus II \& Siklus III

\begin{tabular}{cccc}
\hline \multirow{2}{*}{ KBM } & \multirow{2}{*}{ Jml peserta didik } & \multicolumn{2}{c}{ Ketuntasan belajar } \\
\cline { 3 - 4 } & & Tuntas & Belum tuntas \\
\hline Siklus I & 24 & 16 & 8 \\
Siklus II & 24 & 19 & 5 \\
Siklus III & 24 & 23 & 1 \\
\hline
\end{tabular}

Dari keterangan tersebut di atas, diketahui ada perubahan angka menunjukan kenaikan tingkat penguasaan peserta didik terhadap materi ajar terhadap setiap siklus lebih lanjut dapat dicermati pada tabel di bawah ini:

Tabel 3. Tingkat Penguasaan Peserta Didik Terhadap Materi Ajar

\begin{tabular}{llcc}
\hline \multirow{2}{*}{ No } & $\begin{array}{c}\text { Kegiatan } \\
\text { Pembelajaran }\end{array}$ & Tingkat Penguasaan & Tingkat Perubahan \\
\hline 1 & Siklus I & $67 \%$ & - \\
2 & Siklus II & $79,2 \%$ & $12,2 \%$ \\
3 & Siklus III & $95,8 \%$ & $16,6 \%$ \\
\hline
\end{tabular}

Dari tabel 3. terlihat bahwa dari studi slikus I ke siklus II tingkat penguasaan naik $12,2 \%$. Dari siklus II ke siklus III meningkat lagi menjadi $16,6 \%$. apabila digambarkan dalam bentuk grafik menjadi sebagai berikut : 


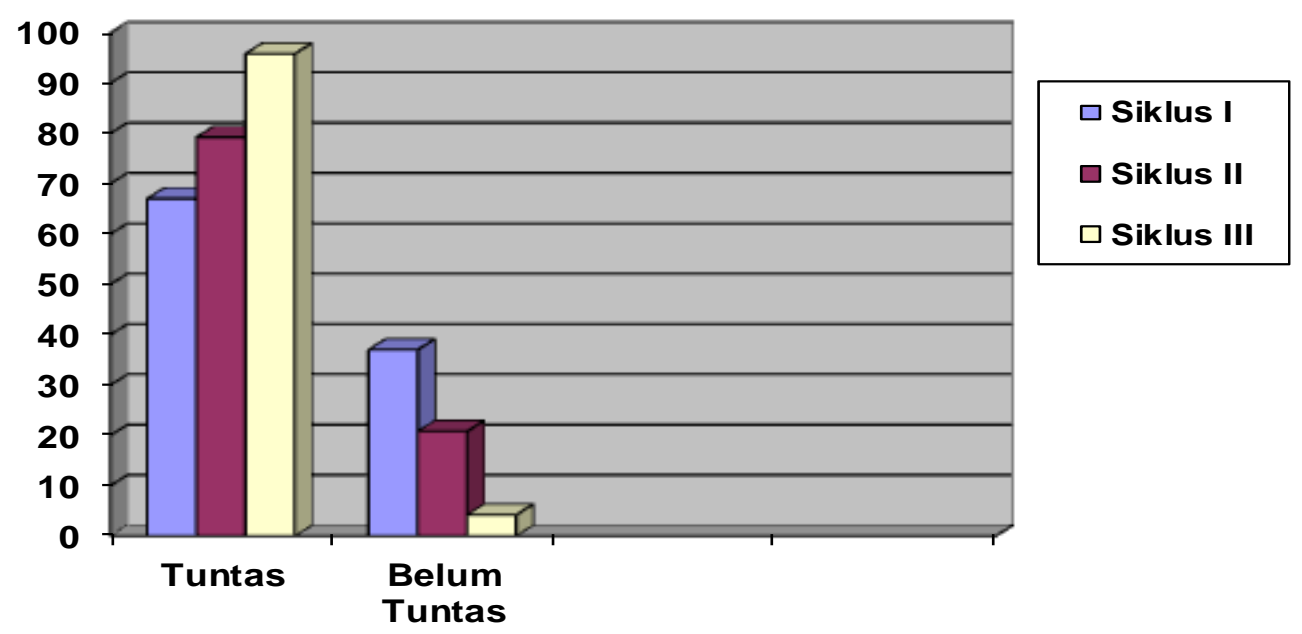

Gambar 3. Ketuntasan Peserta didik

\section{SIMPULAN}

Berdasarkan temuan dan hasil yang diperoleh dari kegiatan pembelajaran siklus 1 sampai siklus 3, maka dapat ditarik kesimpulan sebagai berikut:

1. Sebelum menggunakan media power point interaktif dalam mata pelajaran IPA pada materi sistem peredaran darah pada peserta didik kelas V SD Negeri Cawitali 03 Kecamatan Bumijawa Kabupaten Tegal dari 24 peserta didik yang hadir dan mengerjakan soal evaluasi yang dilakukan diperoleh rata-rata 74 dengan persentase $67 \%$ atau dengan kata lain tidak mencapai KKM 70.

2. Setelah melalui penggunaan media powerpoint interaktif terbukti dapat meningkatkan hasil belajar materi sistem peredaran darah pada peserta didik kelas V SD Negeri Cawitali 03. Hal itu terbukti dengan adanya peningkatan hasil belajar peserta didik yang tuntas belajar dari siklus 1 yang hanya $67 \%$ dengan nilai rata-rata 74 , pada siklus 2 meningkat menjadi $79,2 \%$ dengan nilai rata-rata 77, 8 dan meningkat lagi menjadi 95,8\% pada siklus 3 dengan nilai rata-rata 81,8. Dengan demikian, dapat dikatakan bahwa hasil belajar peserta didik meningkat dan penelitian ini dikatakan berhasil.

\section{DAFTAR PUSTAKA}

Arief, S. (2009). Media pendidikan, pengertian, pengembangan, dan pemanfaatannya. Jakarta: Rajawali Press.

Arikunto, Suharsimi, dkk. 2009. Penelitian Tindakan Kelas. Jakarta: Sinar

Arsyad, Azhar. 2013. Media Pembelajaran. Jakarta: Rajawali Press.

Dahar Ratna. 2011. Teori-Teori Belajar dan Pembelajaran. Jakarta: Erlangga 
Dananjaya Utomo, 2010. Media Pembelajaran Aktif. Bandung: Nuansa

Daryanto. 2010. Media Pembelajaran. Jakarta : Gava Media

Rositawaty, S. 2008. Senang Belajar Ilmu Pengetahuan Alam V Untuk SD/MI Kelas V. (Jakarta: Pusat Perbukuan Kementerian Pendidikan Nasional).

Samatowa, Usman. 2011. Pembelajaran IPA di Sekolah Dasar. (Jakarta: Indeks).

Sanaky, Hujair AH. 2013. Media Pembelajaran Interaktif-Inovatif. (Bantul: Kaukaba Dipantara). 